\title{
Voluntary Assets and Income Declaration Scheme (VAIDS) and Company Income Tax in Nigeria: A Post-Mortem
}

\author{
Onwuka Okwara Onwuka, PhD, ACTI \\ Department of Accountancy \\ Abia State University, Uturu, Nigeria. \\ Ama Ibiam Obasi, PhD, ACA \\ Akanu Ibiam Federal Polytechnic \\ Unwana, Ebonyi State, Nigeria \\ Uche Okoro Orji, MSc, MNIM \\ Department of Accountancy \\ Abia State University, Uturu, Nigeria. \\ Onyinyechi Patience Ekekwe \\ Department of Accountancy \\ Abia State University, Uturu, Nigeria.
}

\begin{abstract}
The contribution of taxation to any economy globally cannot be over emphasized. This research work is on Voluntary Assets and Income Declaration Scheme (VAIDS) and Company Income Tax (CIT): A Post-Mortem. The main objective of this study is to explore the impact of Voluntary Assets and Income Declaration Scheme on company income tax in Nigeria. Time series data were applied in carrying out this research work. Ordinary least square regression analysis was employed in this work with the use of STATA 13 package. The scope of the study is basically focused on the assessment and effect of voluntary assets and income declaration scheme on company income tax in Nigeria from June 2017 to March 2018 a period of 9 months but later extended to July 2018 by the Federal Government of Nigeria. This research focuses on a broad range of issues with the collection of a diversity of data in the field of VAIDS and company income. A literature review was used to determine the theoretical basis for research topic and prior research method conducted on various aspects of relating to VAIDS and company income tax. This work adopted the ex-post-facto research design. The findings reveal that Company Income Tax has an insignificant impact on VAIDS. The work recommends that the voluntary assets and income declaration scheme should be a permanent programme as a separate body should be set up to inspect and ensure the smooth running of the programme.
\end{abstract}

Key words: VAIDS, Tax, Executive, Order, Income

\section{INTRODUCTION}

As part of efforts to improve non-oil revenue amid a global outlook of low oil prices, the then Nigeria's Acting President, Professor Yemi Osinbajo, signed an Executive Order (EO) on the Voluntary Assets and Income Declaration Schemes (VAIDS).

The main objective of the scheme which commended on July 1, 2017 and lasted for a period of one year was to help expand the country's tax base (CITN, 2017). According to FIRS (2017), other objectives of the scheme as announced by the minister of finance, Kemi Adeosun, include 
increasing tax to - GDP ratio from $6 \%$ to $18 \%$ by 2020 and improving compliance with existing tax laws. VAIDS was also expected to curb the use of tax havens, discourage tax evasion and tackle illicit financial flows, with the introduction of VAIDS, the government hopes to encourage voluntary disclosure of previously undisclosed assets and income and the payment of outstanding tax liabilities (Mayowa, 2017).

In one of its reports on voluntary disclosure programmes (VDP), the organization for economic co-operation and development (OECD) described VDPs as "Opportunities Offered by tax administrations to allow previously non-compliant tax payers to correct their tax affairs under specified terms when drafted carefully, voluntary disclosure programmes benefit everyone involved taxpayers making the compliance taxpayers and governments". The Nigerian VAIDS was implemented by Federal Inland Revenue Services FIRS in collaboration with all 36 state Internal Revenue Service (IRS) and the FCT IRS.

While signing the EO on the scheme, Professor Yemi Osinbajo said it had become imperative for the government to do something about the low level of tax compliance, adding that "when people pay taxes they pay more attention to what government is doing. There's a greater level of political and social consciousness.

Taxes are not only about boosting government revenues, when people pay taxes they hold the government to account more. In developed countries, citizens pay their fair share of taxes and they have a say in the way their representatives in government manage government funds.

Considering Nigeria's low tax to GDP ratio and the fact that out of a taxable class of about 69 million people, only 14 million are currently in the tax net, the implementation of VAIDS could go a long way in increasing non-oil revenue, despite having non-oil sector that accounts for up to 93\% of Nigeria's GDP, government's non-oil revenue in 2016 was $\mathrm{N} 2.99$ trillion (or $2.9 \%$ of GDP). Suffice to say, though, that there was a decline in non-oil collection from the $\mathrm{N} 12.08$ trillion recorded in 2015. Nevertheless this does not alter the main issue, which is the dismal performance of the non-oil sector in terms of generating revenue for the government voluntary disclosures regarding tax matters are not new in tax administration. Indeed VDPs are widely used in developed countries, helping to enhance the effectiveness of their tax administration. Voluntary disclosure programmes can generally be grouped into two categories namely permanent or temporary programmes. The Nigerian VAIDS is considered a temporary programme (Olajide, 2017).

The Canadian Voluntary Disclosure Programme is a permanent programme. It gives individuals and companies a second chance to change a tax return that was previously filed. To be eligible it must be voluntary, should an individual or company be contacted by the Canada Revenue Agency before making the disclosure, it won't be considered voluntary.

South Africa also operates a permanent VDP as part of its tax administration. However, a temporary VDP was introduced last year, called the special voluntary disclosure programme (SVDP) it is similar to Nigeria's VAIDS. The SVP Window period is between October 1, 2016 and August, 31 $1^{\text {st }}$, 2017. It was meant for individuals and companies who have not in the past, disclosed tax and exchange control defaults in relation to offshore assets. In developed countries, there are benefits associated with voluntary disclosure, including reduced penalties and an allowance to negotiate for protection against criminal prosecution in serious cases of default. 
In the case of VAIDS, some benefits to individuals and companies were also listed during the rollout such as; immunity from prosecution for tax offences, immunity from tax audit; wavier of interest and wavier of penalties. However, for there to be institutionalization of voluntary disclosure in Nigeria's tax administration, there need to be an enactment of a permanent VDP law by the National Assembly. The South African Revenue Service, Voluntary Disclosure Programme (VDP), which came into effect on October 1, 2012 is administered under the tax administration Act 2011.

According to Yomi and Patrick (2017), VDPs have been found to rake in significant funds for governments, Canada's VDP raked in \$1.3 billion in the 2014-2015 Fiscal year, out of which $\$ 780$ million came from offshore disclosure similarly. The United States offshore Voluntary Disclosure Programme (OVDP) has raked in about $\$ 10$ billion in taxes interest and penalties since 2009. For VAIDS or a future VDP law to be very successful, an efficient and effective tax administration has to be in place. The country's current tax administration is bogged down with several issues, ranging from lack of accurate data, duplicity of taxes and crude collection systems. These issues will need to be dealt with, in his book. The Wealth of Nations, published in 1976, Scottish economist, Adam Smith, outlined the four principles or canons of a tax system;

The subject of every state ought to contribute towards the support of the government, as nearly as possible, in proportion to their respective abilities, that is, in proportion to the revenue which they respectively enjoy under the protection of the state.

\section{Statement of the problem}

The attitude of Nigerians towards taxation is worrisome as many prefer not to pay tax if given the opportunity. The economy continues to lose amount of revenue through the unwholesome practice of tax avoidance and tax evasion. This loss of revenue can change the fortune of many economies. During the period of oil boom the Nigerian government generated $60 \%$ of its revenue from crude oil sales, but after the federal government embark on massive revenue generation through tax.

Nigeria's Tax Revenue contribution to Gross Domestic Product is reportedly one of the lowest in the world compare to other countries. Due to multiple sources of income to taxpayers which brings about false declaration of assets and income tends to lower the generation of revenue and also the total number of qualified taxpayers in Nigeria is just $20 \%$ out of the number of that are qualified to pay tax. This paper intends to evaluate the effect of voluntary assets and income declaration scheme on company income tax in Nigerian.

\section{Objective of the study}

The sole objective of this research work is to evaluate the impact of Voluntary Assets and Income Declaration Scheme on company income tax in Nigeria.

\section{Research question}

The study will provide answer to the following question, based on the objective stated above: Does voluntary assets and income declaration scheme influence company income tax revenue in Nigeria?

\section{Research hypothesis}

The objective of this study is hypothesised as follows:

$\mathbf{H}_{0}$ : Voluntary Assets and Income Declaration Scheme does not have any significant on company income tax 


\section{Concept of VAIDS}

\section{REVIEW OF RELATED LITERATURE}

Tax revenue mobilization as a source for financing development activities in Nigeria has been a difficult issue primarily because of various forms of resistance, such as evasion avoidance and other form of corrupt practices. These activities are considered as sabotaging the economy and are readily presented as part of the reasons for present state of underdevelopment in Nigeria. Therefore, VAIDS comes on the back of a renewed global movement to tackle the problem of illicit financial flows which includes tax evasion. This tax amnesty is critical pillar to support the global exchange of information initiative as many of those that may require tax regularization could do so with full assurance of confidential protection and immunity from penalties tax intentional previous positions could ordinarily have attracted. The voluntary disclosures regarding tax matters are not new in tax administration. VAIDS tends to increase the Gross Domestic Product of the Country and it covers all categories of existing and potential tax payers that are liable to tax in Nigeria and it will be jointly executed by the Federal and State Government through their respective Bodies.

\section{Scope of VAIDS in Nigeria}

The scheme applies to all persons and business entities in default of their tax liabilities and cover assets and income from sources within and outside Nigeria. As noted in the proviso to paragraph II of the order, the rights and status acquired by any participating taxpayer pursuant to the scheme shall vest to the benefit of the taxpayer to the extent provided by law.

It is possible for to argue that the scheme should only apply to those taxes administered by the FIRS given that the order was issued by the Federal Government and considering the constitution of the Federal Republic of Nigeria clearly delineates powers of the federal from the State Governments. It appears however and commendably so, that the benefits under the scheme are available in respect of all taxes administered by the FIRS as well as those administered by all State Boards of Internal Revenue. A possible explanation for the overreaching and all-encompassing nature of the scheme is not far-fetched starting with the seemingly centralized nature of legal regime for taxation in the country coupled with the involvement of the state in the formulation of the scheme. As noted earlier, the NEC which gave the initial approval-in-principle to the scheme, prior to the Issuance of the Order by the Acting President, has as its members, all the Governors of the 36 states in Nigeria and the Governor of the Central Bank of Nigeria. Thus, by granting approval in principle through the NEC, the states Governors on behalf of their states, seem to have sanctioned the scheme.

To further buttress the involvement of the states, the preamble to the order clearly states that the scheme was consequent upon "the determination of the Federal and State Governments to provide an opportunity for taxpayers who are in default under all relevant statutes to voluntarily declare their Assets and income and pay taxes". Similarly, taxation is an item in the exclusive legislative list and the Federal Government plays a supervisory role over tax matters. As a demonstration of the harmony that exists between the Federal Government and the Federating Units, the FIRS Chairman, Mr Babatunde Fowler, recently stated at the $138^{\text {th }}$ Quarterly Meeting of the Joint Tax Board that there is memorandum of the Understanding adopted between the FIRS and State Internal Revenue Service in respect of VAIDS which has been working effectively. He further stated that all the money degenerated from the scheme will be shared between the three tiers of government.

Notwithstanding the wide scope of the VAIDS, the implementation of the scheme across the various states will not pose any difficulty given the reported collaboration that exists amongst the three tiers of Governments. 


\section{Eligibility to participate in VAIDS}

The scheme is open to all persons and entities in default of their tax liabilities such as;

1. Those who earn income or own assets but yet to register with the relevant tax authorities.

2. Registered taxpayers who have additional disclosures to make or need to amend prior disclosures.

3. Registered taxpayers who have not been filling returns as well as those who submit tax returns but have not been fully declaring their taxable income and assets.

4. Persons who are underpaying or under remitting their taxes.

5. Provides opportunity for those who are under a process of tax audit or investigation with the relevant tax authority and those that are engaged in a tax dispute with the relevant tax authority but are prepared to settle the tax dispute out of court.

Notwithstanding the general applicability of the scheme to all taxpayers (Federal and State taxes), an applicant is however, required to fulfil certain preconditions in order to validate any application made under the scheme. Such mandatory requirement are that the applicant must have made a voluntary disclosure which must be full, frank, complete and verifiable in all material respects. In terms of the form, the disclosure must be made using the VAIDS form or in any other form or manner as maybe prescribed under the scheme. The assessment of the tax payable must be carried out by relevant tax authority. It is important for applicants to take note of these requirements as any disclosure that runs afoul of same maybe declared invalid and the applicant may be defined the benefits that would ordinarily inure to a valid applicant.

\section{Benefits and reliefs for voluntary disclosure}

According to Deloitte Nigeria (2017), as a form of tax amnesty, any taxpayer who truthfully and voluntary declares his assets and incomes, complies with regulations and guidelines made pursuant to the scheme and pays all outstanding taxes shall be entitled to the benefits provided under the scheme. Amongst those benefits are immensely unity from tax audit and prosecution for tax offenders, waiver of interest and penalties on unpaid taxes and the option of spreading payment of outstanding liabilities over a maximum period of three years as may be agreed with the relevant tax authority. The wavier however, is without prejudice to any court order or judgment already obtained in respect of any accrued interest or penalty.

A taxpayer who volunteers information under the scheme is equally guaranteed of confidentiality of such information to the extent permitted by law and any tax official or authorized person who breaches the confidentiality of information received or exchange under the scheme without due authorization shall be liable to prosecution under the relevant law. It is important to note that the protection of confidentiality as stated above is in line with section 38 (2) of the Personal Income Tax (Amendment) Act 2011, Section 5(1) of the Petroleum Profit Tax Act 1990, Article 26 of the Double Taxation Relief Order between Nigeria and certain countries which all provide that a member of the relevant tax authority shall treat tax information confidentiality and only disclose as provided by law.

\section{The Federal Board of Inland Revenue (FBIR)}

Taiwo (2017) stated that the Federal Board of Inland Revenue through its operational arm, the Federal Inland Revenue Service, deals with corporate bodies as well as personal income tax for certain categories of individuals viz; members of the Armed Forces, the Nigeria Police, resident of the federal capital territory Abuja, External Affairs Officials and Non-resident individuals. This is the body established by the federal government and it is vested with the power to administer the act and to carry out all acts which may be deemed necessary and expedient of the assessment and collection of tax and shall account for all amount so collected in a manner 
to be prescribed by the Federal Ministry of Finance. The Board has certain reserved to powers which it shall not delegate to other person to perform e.g. power to acquire, hold and dispose of property of any company satisfaction of tax or any judgment debt, power to satisfy forms of return, claims and notice. All taxes collected by the federal Inland Revenue Service go to the Federal Government.

\section{Companies Income Tax (CIT)}

Companies Income Tax Act is the enabling law that governors the collection of taxes on profits made by companies operating in Nigeria excluding companies engaged in petroleum exploration activities. This tax is payable for each year of assessment of the profits of any company at a rate of $30 \%$.

According to Ola (2006) companies income tax administration in Nigeria does not measure up to appropriate standards if good old test of equity, certainty, convenience and administrative efficiency are applied Nigeria will score low considering the following points: Due to inadequate monitoring, persons in the self-employed and unquoted private companies group evade tax. In a study conducted by Festus and Samuel (2007) on company Income Tax and the Nigeria economy, they conclude that company Income Tax is a major source of revenue in Nigeria but non-compliance with the laws and regulations by tax payers is deep in the system because of weak control. There is the need for a general tax reform in the Nigerian company income tax system.

\section{Tax avoidance and the tax evasion practices:}

Tax Avoidance is generally considered as a way of identifying the loophole in the tax laws and then taking advantage of such a loophole to reduce the tax payable, (Olalekan, 2017). For instance, a taxpayer may invest in qualifying capital expenditures that will ordinarily not invest in because of the advantage there from. Because of this, tax avoidance is not considered as an offence. A tax avoidance practices benefit the tax payers at the expense of the state. In the words of Prosphare (2017), the major loophole in the tax law is the area where companies exploit capital allowances on their qualified capital expenditures in use for the purpose of a trade or business. Capital allowance is claimed in replacement for depreciation charge, which is treated as an inadmissible expense for tax purpose. The tax benefits help them to have retained funds in the system to grow their business, tax avoidance is legal. According to Asada (2005), tax avoider is simply one who agrees to his duties in such a way that he pays little or no tax.

Tax evasion is a deliberate Act on the part of the taxpayer not to pay tax due (Adegbie, 2010). This is considered as a criminal offence on the part of the taxpayer. The relevant tax authority may take such steps as it deems fit to recover any such tax and the taxpayer penalized if found guilty. Tax evasion can be partial or total and its degree varies from company to company. There is partial evasion when a company under declares its profits for tax purpose and total evasion of income tax occurs when a company which is already qualified to pay tax refuses to get its evasion of income tax is a serious problem in Nigeria, more so as there is a big gap between actual and potential tax collections by the various levels of government. The criminal act in Nigeria is perpetrated through these medium; total ignorance of the law, lack of faith in the rate which makes evasion more attractive and economical absence of visible benefits accruing to the taxpayers, outright unwillingness to contribute towards the development of the society and ridiculous low penalties prescribed in the laws for late payment of tax (Appah, 2004). 


\title{
Theoretical framework
}

A tax revenue theory maybe derived on the assumption that there need not be any relationship between tax paid and benefit received from state activities in this group, there are several theories as follows:

\section{Benefit theory}

The benefit theory was propounded by William Petty in 1992. According to the benefit theory there is basically an exchange relationship between taxpayers and the state. The state should levy taxes on individual according to benefit conferred on them. This means that, the more benefit a person derives from the activities of the state, the more he should pay to the government. This theory seeks to ensure that each individual's or company tax obligations are as far as possible based on the benefits that he or she receives from the enjoyment of public services. The application of these theories in Nigeria is such that there are various taxes (levies) that are collected in the Local jurisdiction example, in market, bus stands which are collected by various local government authorities, at the end this fund is further used to develop social facilities which results to social benefit to the society members. However, this theory faces various critics such as;

Firstly, the assumption that the tax should be paid by an individual in proportion to benefits conferred by the state on that individual, it quite unrealistic because the benefit derived cannot be correctly measured in terms of money. Benefits purely subjective matter and there is no scientific way to measure the magnitude of benefit and its money value.

Secondly, if benefits accrued to an individual is the basis of taxation, the poor must pay higher tax because in a welfare state the poor get more benefits than the rich from the expenditure of the government. This is clearly unjust and as such an unacceptable proposition.

Thirdly, if the state maintains a certain convection between the benefits conferred and the benefits derived, it will be against the basic principle of the tax. A tax is a compulsory contribution made to the public authorities to meet the expenses of the government and the provisions of general benefit. There is no direct quid pro quo in the case of tax.

\begin{abstract}
Ability to pay theory
Ability to pay theory was developed in 1939 by Kardrick. The ability to pay theory was developed due to inadequacies in benefit and sacrifice theories of taxation. This is the most popular and commonly accepted principle of equity or in accordance with their ability to pay. It appears very reasonable and just that taxes should be levied on the basis of the taxable capacity of an individual. For instance, if the taxable capacity of a person A is greater than the Person B, the former should be asked to pay more taxes than the letter. It seems that if the taxes are levied on this principles as stated above, then the justice can be achieved. However, there are still some difficulties putting this theory in practice.
\end{abstract}

Firstly, it is difficult if not impossible to determine the ability of a person to pay taxes. The term "Ability to Pay" is ambiguous. It leads to question such as should the taxes be charged at a uniform percentage for all taxpayers or is it going to be a higher percentage on high income and low percentage on low income?

Secondly, taxes all the government to offer public goods and services and the users to those goods and services should pay taxes according to extent to which the use public goods and services and not on the basis of how much they have earned. 


\section{The sacrifice theory}

The sacrifice theory was developed by Macullah in 1845. The sacrifice theory attempts to determine the burden that rests upon an individual by virtue of his payment of taxes and how much of his or her income remains for purpose of his own subsistence. According to this theory payment of tax is a sacrifice that an individual or company makes towards the support of the government. The measure of such is, giving up of enjoyments, which is giving up a portion of individual's means (income) of satisfying wants (consumption). Practically the sacrifice theory demands that individuals should only pay tax on that portion of individual's means over and above subsistence. Applicability of this theory is conceptually difficult unless it is expressed in terms of income and consumption.

\section{The cost of service theory}

The cost of service theory was made popular by Van Hock. Some economists were of the view that, if the state charges actual cost of the service rendered to the people, it will satisfy the idea of equity justice in taxation. The cost of service principle can no doubt be applied to some extent in those cases where the services are rendered out of prices. Also, the theory is rejected because no quid pro quo in a tax.

\section{Theory of social influence}

This theory was propounded by Cialdnia Psychological Theory but will however be used as a framework for this study. The theory of social influence as accessed from changing minds explains thus; in 1984, Cialdnia published influence where he discussed on topics like reciprocity, social proof, liking, authority and scarcity.

Reciprocity: It is a belief that when you give you expect in return. It is natural that when taxes are paid government should put the funds to judicious use. Consistency and commitment. This is an idea where government made promises to provide amenities, when this is done the taxpayers are inclined to pay their taxes.

Social Proof: This shows lack of policy implementation where people evade tax and are not punished, copy and the cycle continues.

Liking: When the citizens see good governance they feel like and are obliged to do their civic duties.

Authority: When a citizen knows that by not paying his tax there is consequence for not paying, he has no option than to pay.

Scarcity: If government knows without acting in order to generate money through tax today then the inevitable will happen, that is, lack of money to run the state.

\section{Empirical review}

The core function of the tax revenue as a revenue generating tool in developing countries has been studied by eminent scholars.

Adegble and Fakle (2011) examined the relationship between company income tax and Nigeria's economic development for the period 1981 to 2007. The used GDP to capture the Nigerian economy which was measured against total annual revenue from company income tax for the same period. They employed the use of chi-square and multiple linear regression analysis method to analyse data obtained from both primary and secondary sources. Their variables included various taxes regressed against GDP with an R squared of $98.6 \%$ and an adjusted $\mathrm{R}$ squared of $98.4 \%$ revealing that company income tax's impact on GDP is very high and impressive. It further showed that there is a significant relationship between company income tax and Nigeria economic development and that tax evasion and avoidance are the 
major hindrances to revenue generation. Overall the study, only company income tax which cells for the need to see the impact of all tax revenue on the Nigeria economy.

From the study, ethics of tax evasion, Fagbemi (2017) in Nigeria used a survey for the study. The researcher focused on business taxpayers and left out likely tax evaders like the contractors and professionals like the lawyers, doctors and accounting firms. The analysis of the study used both descriptive and inferential statistics. They found out that the level of tax evasion is significantly higher when government is corrupt than any other views.

Adesi and Gbeyi (2017) in their study, effect of tax avoidance and tax evasion on personal income tax in Nigeria, administered questionnaires on employees of federal Inland Revenue Service in Abuja. Just like Fagbemi (2017) some of the elements in personal income tax like contractors and professionals are left out of the study. ANOVA was used to analyse two hypothesis; the relationship tax avoidance, tax evasion and personal income tax administration in Nigeria, and the relationship between tax, rates, tax avoidance and tax evasion. The researcher use of ANOVA to test relationship brings to question whether the study is measuring effect or relationship. The study found out that good governance will discourage tax avoidance and tax evasion. It equality found out that tax avoidance and evasion is as a result of high tax rate.

Bonu and Pedro (2009) investigated the impact of Income tax rates (ITR) on the economic development of Botswana, the study reveals that the influence of Income Tax Revenue over GDP is not much in economically advanced countries such as Japan, China, UK, USA and Canada, among the advanced countries, Japan has 4\% followed by Canada (9\%), UK (10\%), China, $(11 \%)$ and USA (12\%). In developing nations, the lowest influence of Income Tax over the GDP is found in Mozambique (2\%) followed by Mauritius (4\%), Seychelles (5\%), Tanzania and Zambia (6\% each), Congo (7\%), Lesotho (8\%), Botswana (9\%) whereas a greater influence is found in Malawi (50\%), Angola (36\%), Zimbabwe (14\%), South Africa (13\%) and Namibia (12\%). According to Giligan and Richardson (2005), the tax system that is perceived as unfair by the citizens may likely to be less successful and this will encourage the taxpayers to engage in non-compliant behaviour, which may have adverse effect on economic growth.

Brain (2007) analysed the "effects of tax revenue on economic growth in Uganda's experience for the period 1987-2005. From the study, tax revenue was found to have had an impact on the economic growth level of the country, with direct taxes having a positive effect while indirect taxes had a negative impact. However, he stated that due to time, financial and data constraints, not all essential issues could be analysed the issue arising from this work is the fact that indirect taxes are not easily evaded when it comes to payment because they are paid either on consumption of goods and services or at source and so one expects that they should have a positive impact on a country's economic growth not negative as reported.

Abiola (2010) conducted a research work on the recent developments in company's income taxation in Nigeria and analysed the variables with the use of quantitative survey method and finds out that the Nigeria tax system is unduly complex, skewed low revenue yielding poorly administered anti-federalism largely inequitable and loaded with unduly large number of overlapping taxes which have more nuisance value than revenue value. The study recommended that the tax administration amending act altered some of the penalties under CITA to reflect current realities and make them more administrable.

Jane (2011) carried out research on the impact of tax reform on the general economy of the nation and tested the research variable with the use of ordinary least square regression 
method and find out that tax reforms in Nigeria have not had a significant impact on the macroeconomic stability. It was observe that increase in the tax rate ultimately result in greater burden for the masses through a shift of the tax liability. As a result, tax reforms in Nigeria have created inequalities rather than bridging such the study further recommended that citizens should wake up to their civic responsibilities in terms of tax compliance.

Saidu (2012) conducted a research study on the effect of tax audit on tax compliance in Nigeria with Bauchi State brad of Internal Revenue as a case study. The data generated for the study was analysis with the aid of simple percentage method. The audit towards achieving target revenue that tax revenue reduces the problems of tax evasion and that taxpayers do not usually corporate with the tax audit personnel during the exercise.

The research study further recommends that relevant to tax authority (RTA) at all level should improve the statement of tax audit employed for effectiveness and efficiency.

Basila (2010), in investigating the relationship between VAT and GNP in Nigeria used a data based on VAT revenue figure and GNP figure from 1994 to 2008 obtained from Central Bank of Nigeria statistical bulletin, GNP and VAT figure for that period of study were tested for correlation, the vest revealed a strong Pearson's Product Moment Correlation (PPMC) at about $96 \%$ strength, further a test of significance confirmed that VAT revenue is significantly different at $99 \%$ confidence level in relation to GNP. He concluded that there is a strong positive correlation between VAT revenue and GNP, again as regards to the test of significance, student " $\mathrm{t}$ "-test confirmed that VAT is significantly different in relation to GNP in Nigeria.

Okoye and Gbeyi (2013), used a secondary data that were generated from Federal Inland Revenue Service and Federal Bureau from statistical analysis with the aid of a table and simple percentage while the hypothesis formulated were tested using Product Moment Correlation Coefficient and student in test. The findings revealed that revenue generated through VAT has a significant influence on wealth creation in Nigeria and also that revenue generated through VAT has a significant effect on total tax revenue in Nigeria. Therefore, from their findings the discovered that VAT is the bedrock of wealth creation in Nigeria as well as economic development as it contributes significantly to the nation's Gross Domestic Products (GDP). Therefore, the government must give a degrade attention to taxation in general and VAT in particular, under a stable and conduct socio-political and economic atmosphere.

In their study of the relationship between company income tax and Nigerian economic development, Festus and Samuel (2007) reformed that in Nigeria, the role of tax revenue in promoting economic activities and growth is not felt primarily because of its poor administration, perception and often an undesirable imposition which bears no relation to the responsibilities of citizenship or to the service provided by the government. Their study further revealed that an efficient and effective tax administration results in increased revenue yield but this is not possible because of the presence of evasion and avoidance due to loop holes in tax laws. On the other hand, Adedeji and Oboh (2010) stated that people expect that by sacrificing their private resources to the form of taxes, government is expected to reciprocate by spending public revenue in a way that will enhance their welfare. However, government and tax collectors have been dubiously mismanaging the public treasury. There is high level of manipulation and diversion of tax revenue by the collectors. The dwindling tax revenue as presently witnessed results from lack of encouragement to the taxpayer, due to the fact that there is very little evidence to show for taxes collected. For these reasons, there are increased cases of tax evasion. 
In all the works reviewed, none discussed the concept of VAIDS and company income tax, though the concept is relatively new. This work seeks to close that gap and be one of the foremost works in the area VAIDS and company income tax in Nigeria.

\section{METHODOLOGY}

The scope of the study is basically focused on the assessment and effect of voluntary assets and income declaration scheme on company income tax in Nigeria from June 2017 to March 2018 a period of 9 months but later extended to July 2018 by the Federal Government of Nigeria.

This research focuses on a broad range of issues with the collection of a diversity of data in the field of VAIDS and company income. This research work is designed to address the objective and hypothesis. A literature review was used to determine the theoretical basis for research topic and prior research method conducted on various aspects of relating to VAIDS and company income tax. Statistical model was used in analysing data obtained in the study. The methodology was empirical as it used econometric tools in analysing data obtained for the study. Data obtained from the Federal Inland Revenue Service (FIRS) Nigeria were used in the analysis of the study. This work make use of ex-post-facto research design.

\section{Model specification}

In order to examine the impact of VAIDS on company income tax in Nigeria, a sample linear model is built. The model captures relationship between company income tax and VAIDS. This is represented as thus;

Specified as follows;

$$
\mathrm{CIT}=\mathrm{f}(\mathrm{VAIDS})
$$

$$
\mathrm{CIT}=\mathrm{a}+\mathrm{bVAIDS}+\mathrm{e}
$$

Where: VAIDS = Voluntary Assets and Icome Declaration Scheme.

CIT = Company Income Tax

$\mathrm{e}=$ error term

\section{RESULTS AND DISCUSSION}

The hypothesis was tested using the regression model for CIT and VAIDS. Dummies of 1 were used for the months that VAIDS was in operation and 0 for months that VAIDS was not in operation. The analysis was done using econometric software of STATA 13.

Table 4.1: Sample result for test of hypothesis

- regress cit vaids

\begin{tabular}{r|crc} 
Source & SS & df & MS \\
\hline $\begin{array}{r}\text { Model } \\
\text { Residual }\end{array}$ & $\begin{array}{l}1.1464 e+21 \\
2.1278 e+22\end{array}$ & $\begin{array}{r}1 \\
\text { S4 }\end{array}$ & $\begin{array}{r}1.1464 e+21 \\
6.2581 e+20\end{array}$ \\
\hline Total & $2.2424 e+22$ & 35 & $6.4069 e+20$
\end{tabular}

$$
\begin{array}{lrr}
\text { Number of obs } & = & 36 \\
\mathrm{~F}(1,34) & = & 1.83 \\
\text { Prob }>\mathrm{F} & = & 0.1848 \\
\text { R-squared } & =0.0511 \\
\text { Adj R-squared } & =0.0232 \\
\text { Root MSE } & =2.5 e+10
\end{array}
$$

\begin{tabular}{r|rrrrrr}
\hline cit & Coef. & Std. Err. & $t$ & P > t l & [95\% Conf. Interval] \\
\hline vaids & $1.51 e+10$ & $1.12 e+10$ & 1.35 & 0.185 & $-7.59 e+09$ & $3.79 e+10$ \\
_cons & $2.62 e+10$ & $4.57 e+09$ & 5.73 & 0.000 & $1.69 e+10$ & $3.54 e+10$ \\
\hline
\end{tabular}

Source: Author computation (STATA 13 output) 
On the basis of the above result, the regression equation can be written as:

$$
\text { CIT }=26200000000+15100000000 \text { VAIDS }
$$

From the result of the analysis of $\mathrm{R}^{2}=0.0511 \approx 5.11 \%$. This implies that the independent variable, VAIDS included in the model is able to explain insignificantly $5.11 \%$ of variation in the dependent variable of CIT while the remaining $94.89 \%$ is accounted for by the disturbance term (errors) which are accommodated in the model specified. This implies that the independent variable of VAIDS explains an insignificant/very weak variation in CIT. also, in the above result; the adjusted $\mathrm{R}^{2}$ is 0.0232 which is less than $\mathrm{R}^{2}$ value of 0.0511 . This is because it has adjusted for independent variables, VAIDS in the association with the dependent variable CIT. The coefficient of VAIDS is 15100000 which implies that a unit in VAIDS. The CIT will increase by 151000000 holding all other factors constant.

From the analysis of hypothesis one, we discover that $\mathrm{P}>/ \mathrm{t} /$ of VAIDS is 0.185 and is greater than 0.05 at $95 \%$ confidence interval, we don't have sufficient evidence to accept $\mathrm{H}_{1}$. Therefore, we accept the $\mathrm{H}_{0}$ and conclude that Voluntary Assets and Income Declaration Scheme does not have any significant impact on CIT.

\subsection{CONCLUSION}

The FIRS and the Ministry of Finance would need to work hard to revamp the country's tax administration. Although Executive Chairman of the FIRS, Babatunde Fowler has expressed optimism that the agency and the government will meet their revenue target for VAIDS, the tax agency will need to do more than a temporary disclosure programme to boost tax revenue in the country. It should also look at how a permanent VDP can be embedded in the tax administration.

But the much bigger task is to put in place policies to engender sustainable inclusive economic growth, increase access to funding for small businesses and revitalize the private sector tax revenue plays a key role in building the economy. However, the economy has to be supported to grow and diversify and the economic diversification agenda of the government is hinged on boosting non-oil revenue of which tax revenue is a huge part of.

While VAIDS remains a temporary programme, the tax agency must also ensure punitive measures for tax defaulters are clearly stated. Otherwise VAIDS will soon join the pool of several government programmes that were rolled out with pomp and pageantry but never achieved their objectives.

In designing an effective tax system, the FIRS and the finance ministry must bear in mind the power of taxation, as James Medison, America's Fourth president opined. "The power of taxing people and their property is essential to the very existence of government".

\section{References}

Adedeji, T.O. Oboh, C.S. (2010). An empirical analysis of tax leakages and economic growth in Nigeria. European Journal of Economics, Finance and Administrative Science ISSN 1450-2275 Issue 40 (2012) (C) Euro Journal, Inc. 2012.

Adegbie, F.F. (2010). Customs and exercise duties contribution towards the development and growth of Nigeria economy. European Journal of Economics, Finance and Administrative Sciences, ISSN 1450-2275 Issue 29 (2011). (C) Euro journals, Inc, 2011 http://www.eurojournals.com.

Aderenti, S.A. Sanni, M.R \& Adesina, J.A. (2011). Value, Added Tax and Economic Growth of Nigeria, European Journal of Humanities and Social Science Vol. 10, No. 1 (Special Issue), 2011 (C) Journals of Bank.com (2011. ISSN 2220-9425457. 
Appah, E. (2004). Principles and practice of Nigerian tax revenue: Ezevin Mint printers and publishers, PortHarcourt.

Asada, D. (2005). The administration of personal Income Tax in Nigeria: Some problems areas, working paper, University of Jos.

Bonu, N.S and Pedro Motau P. (2009). The impact of income tax rates (ITR) on the economic development of Botswana, Journal of Accounting and Tax Revenue Vol. 1 Pp. 008-0022.

Brian Musaga (2007). Effects of tax revenue on economic growth (Uganda's experience: 1987-2005).

CITN (2017). Nigerian Tax System and Expectation of VAIDS by CITN education, research and technical. Retrieved from www.citn.org.

Deloitte Nigeria (2017). Increasing Tax Revenue: is a new approach required? Retrieved from www.monday.cm/Nigeria/x/571840/taxauthorities.

Festus, A.F. Samuel, F.A. (2007). Company Income Tax and Nigeria Economic Development, European Journal of Social Sciences - Vol. 22, No. 2.

FIRS (2017). Federal Inland Revenue Services website Nigeria.

Mayowa, T. (2017). Executive Order on the Voluntary Assets Declaration. Retrieved from https://www.thecable.ng.fulltax.

Ola, C.S., (2006). Income tax Law and practice in Nigeria. Heinmann Educational Books Nigeria Plc, Ibadan.

Olajide, 0. (2017). VAIDS and the need for effective tax administration in Nigeria. Retrieved from www. financialnigeria.com/VAIDS.

Olalekan, A. (2017). Tax Amnesty FG get N33.6bn from two firms. Retrieved from $\underline{\text { http://punhng.com. }}$.

Prosphare, (2017). Executive order on the Voluntary Asset and Income Declaration Scheme (VAIDS). Retrieved from http://www.rpshareng.com/news/taxs\%20\&20traiffs.

Taiwo, 0. (2017). FIRS Declares tax amnesty. Retrieved from http://pwcnigeria.com.

Yomi, O. Sege, A. \& Patrick, N. (2017). New Voluntary Asset and Income Declaration Scheme (VAIDS) in Nigeria. Retrieved from http://blog.decloitte.com.ng. 